\title{
The Latent Tuberculin Test after 1-year Therapy with Anti-TNF in Babylon, Iraq
}

\author{
Ali Alkazzaz ${ }^{\text {a }}$ Murtadha Najah Jawad $^{\text {b }}$ Zeyad Tareq Kareem $^{\mathrm{c}}$ \\ ${ }^{a, c}$ Department of Rheumatology, Marjan Teaching Hospital, Babylon, Iraq. \\ ${ }^{b}$ Department of Respiratory Diseases, Marjan Teaching Hospital, Babylon, Iraq. \\ alkazzazali@yahoo.com
}

Submission date:- 20/3/2018 Acceptance date:- 9/5/2018 Publication date:- 25/9/2018

Keywords: rheumatoid arthritis, anti-TNF, latent tuberculosis, tuberculin skin test, Iraq.

\begin{abstract}
Background: Rheumatoid arthritis (RA) patients receiving receive anti-TNF agents are at increased risk of reactivation of latent tuberculosis infection (LTBI). The tuberculin skin test (TST) is widely used to screen LTBI and providing preventive treatment, in an effort to meet the WHO target of a $90 \%$ reduction in TB by 2035 .
\end{abstract}

Objectives: To determine the proportion of TST conversion among RA patients after 1 year of anti-TNF treatment, and association of positive TST result with patients' socio-demographic characteristics and medical history.

Methods: This community-based cross-sectional study was conducted at the department of Rheumatology of Marjan Teaching Hospital in Iraq, for a period of 1 year. Patients with RA/and spondyloarthropathy, and who received antiTNF therapy for $>1$ year, underwent TST. Their demographic data and medical history were also obtained. All statistical analysis was performed using SPSS (Version 20) and, $p<0.05$ was considered as a significant. Data from the baseline and 1 year follow-up was subjected to the Kolmogorov-Smirnov test to determine whether they were normally distributed. Chi-Square test used to test significance of TST among etanrecept and infliximab at the end of the study.

Results: A total of 96 patients were enrolled, including $55(57.3 \%)$ males and 41 (42.3\%) females with average age of 41.1, and mostly 68 (70.8\%) from Babylon Governorate of Iraq. A total of 40 (41.7\%) patients had rheumatoid arthritis alone, and the remaining $56(58.3 \%)$ had a comorbidity of spondyloarthropathy. Majority of the patients $65(67.7 \%)$ received the biological agent infliximab, while 31 (32.3\%) patients received Etanercept for RA for a period of 1 year. There was a statistically significant decreasing in the median ESR and disease activity from the baseline to the end of the study (p-value <0.01). There was no significant difference in TST results based on gender or age. Both infliximab and etanrecept were significantly associated with a decreasing in ESR and disease activity

Conclusion: This study has shown that there was very low TST conversion among RA patients after 1 year of antiTNF treatment and, age and gender were not associated with TST.

\section{1- Introduction}

Rheumatoid arthritis (RA) and spondyloarthropathy are autoimmune diseases characterized by persistent synovitis and systemic inflammation due to the release of a potent cytokine TNF- $\alpha$, which in turn releases other cytokines (IL1 and IL6). Blockade of TNF- $\alpha$ using anti-TNF agents has revolutionized the treatment of RA and other systemic inflammatory diseases. The efficacy of the anti-TNF agents such as Etanercept and Infliximab for RA has been demonstrated in large-scale trials0-0]. However, patients receiving anti-TNF agents are at an increased risk of fungal and bacterial infection, particularly reactivation latent tuberculosis infection (LTBI)0].

LTBI is a state of persistent immune response to stimulation by Mycobacterium tuberculosis (M. tuberculosis) antigens without evidence of clinically manifested active TB. About one-third of the world's population is estimated to 
have LTBI. The lifetime risk of reactivation for a person with documented LTBI is estimated to be 5-10\% 0]. The reactivation of TB can be averted by screening for high risk individuals and preventive treatment.

In the absence of a standard diagnosis for LTBI, the tuberculin skin test (TST) an easy and inexpensive screening test available worldwide, despite concerns over its sensitivity and specificity. TST is a measure of the delayed-type hypersensitivity reaction to intradermal inoculation of purified protein derivative, a crude mixture of $>200$ M. tuberculosis proteins 0]. Due to the inability of PPD to distinguish between TB infection and Bacille Calmette-Guerin (BCG) induced reactivity, non-infected person may develop a false-positive TST result. Thus, it is recommended that a previous history of BCG vaccination should be considered while interpreting skin test results 0 ].

Tuberculosis is highly endemic in Iraq, with an estimated incidence of 45 /100000 population (i.e. estimated total new TB cases is around 15000 per year), prevalence of 74/100000 and mortality of 3/100000 0].

The WHO has developed guidelines for the management of LTBI to facilitate achievement of a $90 \%$ reduction in TB incidence and a 95\% reduction in TB deaths by 20350]. Thus this community-based cross-sectional study conducted in Iraq to determine the proportion of TST conversion among patients after one year of starting biological treatment. In addition, we assessed the association of positive TST result with patients' socio-demographic characteristics and medical history.

\section{2- Materials and Methods}

This was a community-based cross-sectional study conducted at the department of rheumatology of Marjan teaching hospital in Iraq, for a period of 1 year (1st January 2016 to 30th December 2016).

\section{3- Population of the Study}

Male and female outpatients aged $\geq 18$ years diagnosed with rheumatoid arthritis or/and spondyloarthropathy, and who received anti-TNF therapy with biological agents (etanrecept, infliximab) for more than one year, were randomly selected for this study.

Patients with active TB, positive TST before starting biological treatment, and serious medical illness (diabetes mellitus, uremia, malignancy, and HIV infection) were excluded from this study.

\section{4- Screening}

All patients were screened for the following before enrollment in this study:

- Negative TST before the start of anti-TNF therapy

- Normal X-ray results

- No evidence of active and latent TB at time of starting the anti-TNF therapy.

\section{5- Data Collection}

Demographic data (age, residence area, occupational state) and medical history (history of TB, history of contact with TB patient, medication history, ESR results before (Baseline) and after (New) biological treatment, BCG vaccination and scar status) was obtained from patients.

\section{6-Tuberculin Skin Test}

TST was performed in the respiratory unit of Marjan Teaching Hospital using the Mantoux technique. Five international units of Purified Protein Derivative (PPD RT23, Staten Serum Institute, Copenhagen, Denmark) (kept refrigerated and away from light at The Chest and Respiratory Disease Institute), were applied by an intradermal injection in the middle third of the inner forearm. The skin reaction was quantified 48 to 72 hours after the injection by a pulmonologist. Using a transparent ruler, the largest transverse diameter of indurations was measured in millimeters.

\section{7-Interpreting TST Results:}

- If no indurations developed, it was considered as $0 \mathrm{~mm}$. Erythema of any size without indurations was considered as $0 \mathrm{~mm}$.

- If indurations developed it was reported as either $\geq 10 \mathrm{~mm}$ or $<10 \mathrm{~mm}$. Indurations $\geq 10 \mathrm{~mm}$ were considered as positive TST. Only patients with positive TST were sent for chest radiography.

- Patients who did not complete the test were excluded from the study. 


\section{8- Statistical Analysis}

Categorical variables such as sex were presented in frequency tables (number and percent), while continuous variables such as age were provided as descriptive statistics (mean, standard deviation, median, minimum, maximum and interquartile range). Data from the baseline and 1 year follow-up evaluations was subjected to the KolmogorovSmirnov test to determine whether they were normally distributed. Chi-Square test used to test significance of TST among etanrecept and infliximab at the end of the study. ESR was calculated among etanrecept and infliximab at baseline and at end of the study. Significant group differences over time were calculated using the Mann-Whitney test. Wilcoxon's rank sum test was used to compare ESR values between baseline and at the end of the study by using etanrecept and infliximab.

All statistical analysis was performed using SPSS (Version 20) and, $\mathrm{p}<0.05$ was regarded as significant.

\section{9- Results}

\section{1-9 Demographics}

A total of 96 patients were enrolled, including 55 (57.3\%) males and 41 (42.3\%) females with age ranging from 20 to 65 (average 41.1) years. Most of the patients 68 (70.8\%) are belonged to the Babil Governorate of Iraq.

A total of $40(41.7 \%)$ patients had rheumatoid arthritis alone, and the remaining $56(58.3 \%)$ had a comorbidity of spondyloarthropathy. Majority of the patients $65(67.7 \%)$ received the biological agent etanrecept, while $31(32.3 \%)$ patients received infliximab for RA for a period of 1 year.

\section{2-9 Medical History}

Of the 96 patients that took the TST, 8 (8.3\%) patients tested positive for LTBI but had normal findings on X-ray. None of the patients had a history of TB and all patients tested negative for hepatitis. Majority of the patients 87 $(92.6 \%)$ had the BCG scar.

Medication history revealed that majority of the patients were prescribed steroids 59 (61.5\%), followed by methotrexate $39(40.6 \%)$. The remaining 23 patients used one of the following drugs rituximab, humera, anabril, sulfasalazine, cyclophosphamide, cyclosporine, disease-modifying anti-rheumatic drugs, or hydroxychloroquine.

\section{3-9 Erythrocyte Sedimentation Rate}

There was a statistically significant decreasing in the median ESR from the baseline to the end of the study (pvalue <0.01) (Table 1).

Table 1 ESR at Baseline and New

\begin{tabular}{|c|c|c|c|c|}
\hline \multirow{2}{*}{ ESR } & \multicolumn{3}{|c|}{ Percentiles } & \multirow{2}{*}{ Wilcoxon Test } \\
\cline { 2 - 4 } & Q1 & Median & Q3 & \\
\hline Baseline & 15.25 & 32.00 & 47.75 & $<\mathbf{0 0 0 1}$ \\
\hline New & 11.00 & 20.00 & 33.75 & \\
\hline
\end{tabular}

\section{4-9 Anti-TNF}

Of the 31 patients receiving etanrecept, none were positive for TST. Whereas, $8(12.3 \%)$ of the 65 patients receiving infliximab were positive and $57(87.7 \%)$ were negative for TST. There was a statistically significant difference in the TST results between etanrecept and infliximab (p-value $=0.041$ ) (Table 2). None of the patients developed active TB during the 1 year follow-up. 
Table 2 Biological agent and TST

\begin{tabular}{|c|c|c|c|c|c|c|}
\hline & & & Tubercu & & & \\
\hline & & & Positive & Negative & Total & $\begin{array}{l}\text { Chi-Square } \\
\text { Tests }\end{array}$ \\
\hline B-Agent & Etanrecept & $\mathrm{N}(\%)$ & $0(0)$ & $31(100)$ & $31(00)$ & \\
\hline & Infliximab & $\mathrm{N}(\%)$ & $8(12.3)$ & 57 (87.7) & $65(100)$ & 0.041 \\
\hline Total & & $\mathrm{N}(\%)$ & $8(8.3)$ & 88 (91.7) & $96(100)$ & \\
\hline
\end{tabular}

\section{5-9 TST results stratified by age group (<40 years and $>40$ years)}

A total of 48 patients were $<40$ years old, of which 3 patients tested positive and 45 tested negative for TST. A total of 48 patients were $>40$ years old, of which 5 patients tested positive and the remaining 43 tested negative for TST. The difference in TST results between the 2 age groups was not statistically significant (p-value=0.465) (Table 3 ).

Table 3 Age Group and TST

\begin{tabular}{|c|c|c|c|c|c|c|}
\hline & & & Tubercu & & & \\
\hline & & & Positive & Negative & Total & Tests \\
\hline Group & $\leq 40$ & $\mathrm{~N}(\%)$ & $3(6.3)$ & 45 (93.8) & $48(100)$ & \\
\hline & $>40$ & $\mathrm{~N}(\%)$ & $5(10.4)$ & $43(89.6)$ & $48(100)$ & 0.460 \\
\hline Total & & $\mathrm{N}(\%)$ & $8(8.3)$ & 88 (91.7) & $96(100)$ & \\
\hline
\end{tabular}

\section{6-9 TST results stratified by gender}

The TST results were similar in males and females and not statistically significant ( $p$-value $=0.290)$ was (

Table 5).

Table 4 Gender and TST

\begin{tabular}{|c|c|c|c|c|c|c|}
\hline & & & \multicolumn{2}{|c|}{ Tuberculin Test } & \multirow[b]{2}{*}{ Total } & \multirow[b]{2}{*}{ Chi-Square Tests } \\
\hline & & & Positive & Negative & & \\
\hline \multirow[t]{2}{*}{ Sex } & Male & $\mathrm{N}(\%)$ & $6(10.9)$ & 49 (89.1) & $55(100)$ & \multirow{3}{*}{0.290} \\
\hline & Female & $\mathrm{N}(\%)$ & $2(4.9)$ & $39(95.1)$ & $41(100)$ & \\
\hline \multicolumn{2}{|c|}{ Total } & $\mathrm{N}(\%)$ & $8(8.3)$ & 88 (91.7) & $96(00)$ & \\
\hline
\end{tabular}

\section{7-9 TST results stratified by anti-TNF}

There was a statistically significant decreasing in the median ESR between Baseline and New visit associated with the use of both etanrecept ( $\mathrm{p}<0.001$, Wilcoxon W Test) and infliximab ( $\mathrm{p}=0.014$, Wilcoxon W Test) (Table 5). 
There was a statistically significant difference in median ESR at Baseline visit between etanrecept and infliximab ( $\mathrm{p}=0.014$, Mann-Whitney U test), while there was no statistically significant difference in the median ESR at New visit ( $\mathrm{p}=0.164$, Mann-Whitney U test) (Table 5).

Table 5 ESR with etanrecept and infliximab between baseline and new visit

\begin{tabular}{|c|c|c|c|c|c|c|}
\hline & & Baseline & isit & New Vis & & Wilcoxon \\
\hline & & Median & Q1-Q3 & Median & Q1-Q3 & \\
\hline & Etanrecept & 40 & $\angle 0-32$ & 20 & $18-35$ & $<0.001 * * *$ \\
\hline ESR & Infliximab & 30 & $13-46$ & 20 & $9-32.5$ & $<0.014^{*}$ \\
\hline & Mann-Whitney U & $0.018 *$ & & $0.164(\mathrm{~N}$ & & \\
\hline
\end{tabular}

*** Very highly statistically significant, * Statistically significant, (NS) Not statistically significant

\section{0- Conclusion}

This study has shown that there was very low TST conversion among RA patients after 1 year of anti-TNF treatment and, age and gender were not associated with TST.

\section{1-Discussion}

The diagnostic accuracy of TST in the detection of LTBI is high among patients with inflammatory diseases even in the setting of immunosuppression0.

ESR is a non-specific marker of inflammation and is elevated in a number of noninfectious (RA) and infectious conditions, including TB. The findings from our study show a significantly decreased ESR after 1 year of treatment with anti-TNF agents, thus indicating efficacy of both biological agents (etanrecept and infliximab) in the treatment of RA. This was in agreement with the clinical efficacy of these agents in several clinical trials[0],0]. In addition, there was no statistically significant difference in outcome between the 2 biological agents.

Anti-TNF treatment has been documented as one of the factors associated with increased risk of progression of TB. The risk of TB increased up to 20 -fold with $43 \%$ of TB cases within the first 90 days of administration of anti-TNF therapy, namely infliximab0]. The findings from our study showed that both infliximab and etanrecept were significantly associated with a decrease in ESR

Unlike the study by Borgdorff MW et al which showed an association between males and increased age with TB, our study did not show any significant differences in TST results based on gender or age0].

TB did not develop in any of the 96 patients in this study who were on anti-TNF therapy was for year. The 8 patients who tested positive upon TSTS, showed no abnormality on X-ray.

Limitation of the study is that, although the TST approach increases the detection of remote infection, it may also increase the false-positive rate, leading to a unnecessary prophylactic treatments.

\section{2- Acknowledgement}

The authors would like to thanks ClinArt MENA for providing data analysis and medical writing services. 


\section{CONFLICT OF INTERESTS There are no conflicts of interest.}

\section{3- References}

[1] R. Maini, EW. St Clair, F. Breedveld et al. Ir antibody) vs placebo in rheumatoid arthritis patient: ATTRACT Study Group. Lancet.;354:1932-9. 1999

[2] P.E. Lipsky, D.M. van der Heijde, E.W. St Clair et al. "Infliximab and methotrexate in the treatment of rheumatoid arthritis". Anti-Tumor Necrosis Factor Trial in Rheumatoid Arthritis with Concomitant Therapy Study Group. $N$ Engl $J$ Med. 343:1594-602. 2000.

[3] M.E. Weinblatt, J.M. Kremer, A.D. Bankhurst et al. "A trial of etanercept, a recombinant tumor necrosis factor receptor:Fc fusion protein, in patients with rheumatoid arthritis receiving methotrexate". N Engl J Med. 340:253-9. 1999

[4] L.W. Moreland, M.H. Schiff, S.W. Baumgartner et al. "Etanercept therapy in rheumatoid arthritis. A randomized, controlled trial". Ann Intern Med;130:478-86.1999.

[5] L.Carmona, C.Hernández-García, C. Vadillo, et al. "Increased risk of tuberculosis in patients with rheumatoid arthritis". J Rheumatol. 30(7):1436-14392003.

[6] World Health Organization. Latent TB Infection fact sheet. 2014. http://www.who.int/tb/challenges/ltbi factsheet 2014.pdf?ua=1

[7] S. Nayak and B. Acharjya. "Mantoux test and its interpretation". Indian Dermatol Online J. 3(1):2-6. 2012.

[8] R. Menzies, B.Vissandjee."Effect of bacille Calmette-Guerin vaccination on tuberculin reactivity". Am Rev Respir Dis. 145:621-625. 1992

[9] Tuberculosis in the world and Iraq. Available from: http://phd.iq/LionImages/PDFStore/(revised\%20curriculum)references.pdf

[10] H. Getahun, A. Matteelli, I. Abubakar, et al."Management of latent Mycobacterium tuberculosis infection: WHO guidelines for low tuberculosis burden countries". Eur Resp J. 46(6):1563-1576. 2015.

[11] T. Cagatay, M. Aydin, S. Sunmez, P. Cagatay, Z. Gulbaran, A. Gul, et al. "Follow-up results of 702 patients receiving tumor necrosis factor-alpha antagonists and evaluation of risk of tuberculosis". Rheumatol Int. 30(11):145963. 2010.

[12] H.E. Seymour, A. Worsley, J.M. Smith, S.H.L. Thomas."Anti-TNF agents for rheumatoid arthritis". British Journal of Clinical Pharmacology. 51(3):201-208. 2001

[13] L.W. Moreland, M.H.Schiff, S.W. Baumgartner, et al. "Etanercept therapy in rheumatoid arthritis. A randomized, controlled trial”. Ann Intern Med. 130:478-486. 1999.

[14] R.S. Wallis, M. Broder, J. Wong, A. Lee, L.Hoq." Reactivation of latent granulomatous infections by infliximab". Clin. Infect. Dis. 41(3), S194-S198. 2005.

[15] M.W. Borgdorff, N.J.D. Nagelkerke, Haas PEWD, Soolingen DV. "Transmission of Mycobacterium tuberculosis depending on the age and sex of source cases". Am J Epidemiol. 154(10):934-43. 2001. 
لمحة عامة: مرضى التهاب المفاصل الرثثي الذين يستخدمون ادوية مضادة لعوامل نخر الورم هم في حالة زيادة خطورة تحفيز إصابات التدرن الخامل. فحص التدرن الجلدي يستخدم بصورة واسعة للكثف عن التدرن الخامل ولأعطاء الادوية الوقائية , للوصول الى هدف منظمة الصحة العالمية

الأهداف: لتحديد نسبة تحول فحص التدرن الجلدي بين مرضى التهاب المفاصل الرثوي بعد سنة من استخدام ادوية مضادات عوامل نخر الورم وعلاقة

$$
\text { فحص التدرن الجلدي الموجب مع الخصائص الاجتماعية والديموغر افية و التاريخ المرضي. }
$$

الطريقة: هذه الدراسة مقطعية نم اجر اؤها في قسم المفاصل في مسنتفى مرجان التعليمي في العراق , لمدة سنة واحدة. المرضى الذين يعانون من التهاب المفاصل الرثوي واعتلال الفقار والذين يستخدمون ادوية مضادات عوامل نخر الورم لفترة اكثز من سنة, خضعو جميعا لفحص التدرن الجلدي. البيانات الديمو غر افية و التاريخ المرضي تم اخذه أيضا ـ كل البيانات الإحصائية تم اخضاعها لبرنامج SPSSالنسخة . ب واعتبرت قيمة اقل من 0.05 ذات قيمة ملحوظة. البيانات الماخوذة من الأساس وبعد سنة من المتابعة تم اخضاعها لفحص كولموكَوروف - سيمينوف لتحديد فيما اذا كانت البيانات تم توزيعها بشكل طبيعي • فحص مربع كاي استخدم التقييم دقة فحص التدرن الجلدي بين علاج Etanrcept و Infliximab في نهاية الدراسة.

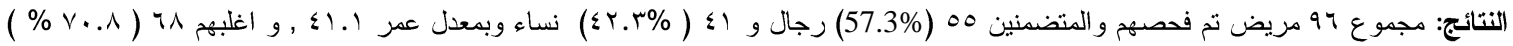

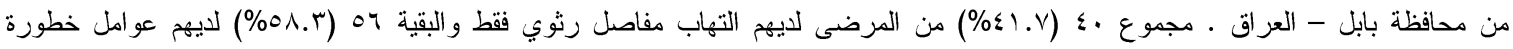
الاعتلال الفقاري. اغلب المرضى 0؟ (Infliximab) بينما اس (r.v\% استخدمو العلاج البايولوجي ) من المرضى استخدمو علاج خلال فترة سنة واحدة ـ لوحظ وجود قيمة ملحوظة بين نقص معدل فحص ESR وفعالية المرض من خط الأساس الى نهاية الدراسة (Etanrcept) (اقل من ا ...) ـ لم يتم يكن هنالك فرق ملحوظ بين نتائج فحص التدرن الجلدي المعتمد على الجنس او العمر ـ كلا العلاجين لوحظ ارتباط ملحوظ

$$
\text { بينهم وبين نقص الـ ESR و فعالية المرض. }
$$

الاستنتاج: هذه الدراسة أظهرت وجود تحول طفيف لفحص التدرن الجلدي بين مرضى الروماتيزم الرثوي بعد سنة من العلاج بمضادات عوامل نخر

$$
\text { الورم, وان العمر والجنس لم ترتبط بفحص التدرن الجلدي. }
$$

الكلمات الدالة: التهاب الدفاصل الروماتيدي، عامل النخر الورمي، التدرن الخامل، فحص التدرن الجلدي، العراق. 